\title{
Evaluation of the pathogenicity of different strains of Clavibacter michiganensis subsp. sepedonicus from NCPPB collection in United Kingdom
}

\section{Ocena patogeniczności wybranych szczepów Clavibacter michiganensis subsp. sepedonicus pochodzących z kolekcji NCPPB w Wielkiej Brytanii}

\author{
Grzegorz Gryń ${ }^{1 *}$, Teresa Pastuszewska ${ }^{1}$, Włodzimierz Przewodowski ${ }^{2}$
}

\begin{abstract}
Summary
The aim of the study was to evaluate the cellulolytic activity, mucoid diversity and pathogenicity of selected strains of Clavibacter michiganensis subsp. sepedonicus ( $\mathrm{Cms}$ ) from National Collection of Plant Pathogenic Bacteria (NCPPB), York in United Kingdom in relation to eggplant (Solanum melongena). The disease symptoms on test plants range from 6.1 to $38.4 \%$ and two strains had no signs of infection. Hydrolysis zones of carboxymethylcellulose in the plate test resulted in high heterogeneity and ranged from 0.33 to $4.29 \mathrm{~mm}$. High virulence of $\mathrm{Cms}$ strains in bioassay was observed with the increase of enzyme activity. The obtained results indicate that the correlation between pathogenicity of selected strains on eggplants and mucoid based on optical density of suspensions was significant at the level of -0.54 .
\end{abstract}

Key words: virulence factors; Clavibacter michiganensis subsp. sepedonicus; mucoid strain; cellulolytic activity

\section{Streszczenie}

Celem przeprowadzonych badań była ocena właściwości celulolitycznych, zróżnicowania mukoidalnego oraz patogeniczności w stosunku do bakłażana (Solanum melongena) wybranych szczepów Clavibacter michiganensis subsp. sepedonicus (Cms) pochodzących z National Collection of Plant Pathogenic Bacteria (NCPPB), York w Wielkiej Brytanii. Objawy chorobowe na roślinach testowych kształtowały się na poziomie od 6,1 do 38,4\%, dla dwóch szczepów nie stwierdzono symptomów porażenia. Strefy hydrolizy karboksymetylocelulozy w teście płytkowym wykazały dużą niejednorodność i wynosiły od 0,33 do 4,29 mm. Wraz ze wzrostem aktywności enzymu obserwowano wzrost wirulencji bakterii $\mathrm{Cms}$ w teście biologicznym. Korelacja patogeniczności szczepów określona w teście na bakłażanach i mukoidalności stwierdzonej na podstawie gęstości optycznej zawiesin była istotna i wyniosła -0,54.

Słowa kluczowe: czynniki wirulencji; Clavibacter michiganensis subsp. sepedonicus; mukoidalny szczep; aktywność celulolityczna

\footnotetext{
Instytut Hodowli i Aklimatyzacji Roślin - Państwowy Instytut Badawczy

${ }^{1}$ Oddział Bydgoszcz

Powstańców Wielkopolskich 10, 85-090 Bydgoszcz

${ }^{2}$ Zakład Nasiennictwa i Ochrony Ziemniaka

Bonin 3, 76-009 Bonin

*corresponding author: g.gryn@ihar.bydgoszcz.pl
} 


\section{Wstęp / Introduction}

Clavibacter michiganensis subsp. sepedonicus (Cms), sprawca bakteriozy pierścieniowej stanowi poważne zagrożenie dla upraw ziemniaka. Powoduje znaczny wzrost kosztów produkcji wynikający ze straty plonów oraz wprowadzenia kwarantanny w miejscu produkcji ziemniaków. Rozprzestrzenianie się bakterii $\mathrm{Cms}$ następuje głównie przez porażony materiał sadzeniakowy oraz zanieczyszczone powierzchnie maszyn rolniczych stosowanych w uprawie ziemniaków (Ramey i wsp. 2004; van der Wolf i wsp. 2005a, b; Danhorn i Fuqua 2007; Harding i wsp. 2014). Bardzo ważne jest poznanie mechanizmów pozwalających bakteriom Cms zasiedlać wiązki przewodzące rośliny żywicielskiej. Stwierdzenie obecności komórek $C m s$ w materiale pobranym z części nadziemnej roślin lub bulw ziemniaka, nie oznacza wystąpienia charakterystycznych objawów chorobowych na roślinie (latentna postać choroby). Występowanie symptomów choroby w postaci chloroz liści, więdnięcia części łodyg, zmian $\mathrm{w}$ tkance przewodzącej bulw zależy od odmiany ziemniaka, koncentracji i wirulencji patogena w roślinie oraz czynników środowiskowych (Westra i wsp. 1994; Kawchuk i wsp. 1998; Pastuszewska i Junosza Kisielewska 2004; Hill i wsp. 2011). Wykrywanie czynnika etiologicznego bakteriozy pierścieniowej ziemniaka oparte jest na zastosowaniu testów immunofluorescencji pośredniej, izolacji na podłożach półselektywnych, testu biologicznego i metody fluorescencyjnej hybrydyzacji in situ (FISH - fluorescent in situ hybridization) lub łańcuchowej reakcji polimerazy (PCR - polymerase chain reaction) (Pastrik 2000; Dyrektywa Komisji 2006/56/WE).
Izolowane z roślin bakterie Cms mogą różnić się stopniem patogeniczności (wirulencją). Spośród poznanych czynników wirulencji wymienia się: wydzielane zewnątrzkomórkowo enzymy celulolityczne, białka indukujące nadwrażliwość oraz wytwarzane otoczki egzopolisacharydowe polimery zewnątrzkomórkowe (EPS - extracellular polymeric substances) (Metzler i wsp. 1997; Nissinen i wsp. 2001; Bentley i wsp. 2008; Hogenhout i Loria 2008). Pozakomórkowe substancje wytwarzane przez komórki Cms pełnią wiele istotnych funkcji. Wśród składników występujących w otoczce bakterii Cms, wymienia się cztery główne komponenty, o różnej masie cząsteczkowej, zbudowane z fukozy, galaktozy, glukozy i mannozy (Westra i Slack 1992). Warstwa śluzu zabezpiecza komórki bakterii przed utratą wody, stanowi barierę przed czynnikami zewnętrznymi. Otoczka jest również miejscem wymiany jonowej oraz magazynuje składniki odżywcze i wiąże związki toksyczne (Jahr i wsp. 1999; Gartemann i wsp. 2003).

Rola otoczek śluzowych bakterii w patogeniczności jest dyskusyjna. Badania relacji roślina-patogen, skłaniają do podejrzewania EPS o utrudnianie reakcji obronnej rośliny. Ponadto EPS umożliwiają adhezję bakterii $\mathrm{Cms}$ do powierzchni biotycznych i abiotycznych, ułatwiają kolonizację komórek gospodarza i tworzenie biofilmu (Rudrappa i wsp. 2008). Zdaniem wielu badaczy czynnikiem wirulencji o największym znaczeniu jest produkcja enzymów celulolitycznych, proteolitycznych i amylolitycznych (Baer i Gudmestad 1995; Metzler i wsp. 1997; Laine i wsp. 2000; Holtsmark i wsp. 2008). Geny kodujące enzym celulazę $($ celA) zlokalizowane są w plazmidzie pCS1 (Laine i wsp. 2000; Nissinen i wsp. 2001).

Tabela 1. Lista badanych szczepów Clavibacter michiganensis subsp. sepedonicus

Table 1. List of tested strains of Clavibacter michiganensis subsp. sepedonicus

\begin{tabular}{l|c|c}
\hline \multicolumn{1}{c|}{$\begin{array}{c}\text { Szczep Cms } \\
\text { Strain of } C m s\end{array}$} & $\begin{array}{c}\text { Data wprowadzenia do kolekcji } \\
\text { Date of introduction to the collection }\end{array}$ & $\begin{array}{c}\text { Kraj pochodzenia } \\
\text { Country of origin }\end{array}$ \\
\hline NCPPB 299 & 1951 & Kanada - Canada \\
\hline NCPPB 378 & 1956 & Szwecja - Sweden \\
\hline NCPPB 379 & 1956 & Szwecja - Sweden \\
\hline NCPPB 2138 & 1968 & Kanada - Canada \\
\hline NCPPB 3294 & 1983 & Belgia - Belgium \\
\hline NCPPB 3295 & 1983 & b.d. - n.d. \\
\hline NCPPB 3296 & 1983 & Belgia - Belgium \\
\hline NCPPB 3324 & 1984 & Czechy - Czech Republic \\
\hline NCPPB 2140 & 1968 & Norwegia - Norway \\
\hline NCPPB 3385 & 1985 & Wielka Brytania - United Kingdom \\
\hline NCPPB 3896 & 1994 & Ukraina - Ukraine \\
\hline NCPPB 3898 & 1994 & Kanada - Canada \\
\hline NCPPB 3917 & 1994 & Cypr - Cyprus \\
\hline NCPPB 4229 & 2001 & Szwecja - Sweden \\
\hline NCPPB 4053 & 1999 &
\end{tabular}

b.d. - brak danych - n.d. - no data 
Celem badań była charakterystyka patogeniczności wybranych szczepów $C$. michiganensis subsp. sepedonicus. W badaniach użyto 15 szczepów pochodzących z National Collection of Plant Pathogenic Bacteria (NCPPB), York w Wielkiej Brytanii (tab. 1).

\section{Materiały i metody / Materials and methods}

W doświadczeniu przeprowadzono test płytkowy określający aktywność celulolityczną, test biologiczny na roślinie bakłażana, ocenę wizualną kolonii oraz metodykę określającą stopień mukoidalności użytych do badania szczepów na podstawie pomiaru gęstości optycznej zawiesin.

Aktywność celulolityczną stwierdzono po posianiu zawiesin Cms (5 $\mu$ l, w postaci kropli) o koncentracji $10^{7} \mathrm{jtk} / \mathrm{ml}$ na pożywkę zmodyfikowaną M9 z dodatkiem soli sodowej karboksymetylocelulozy (cmc) (Meletzus i wsp. 1993). Po 10 dniach inkubacji w temperaturze $21^{\circ} \mathrm{C}$ zaznaczono obszar kolonii bakterii, a następnie wybarwiono płytki $0,1 \%$ roztworem czerwieni Kongo. Po 15 minutach płytki odbarwiono $1 \mathrm{M}$ roztworem $\mathrm{NaCl}$. Zmierzono promień niezabarwionego „halo” wokół kolonii bakteryjnej świadczący o ilości produkowanego enzymu rozkładającego celulozę. Doświadczenie przeprowadzono w trzech powtórzeniach.

W teście patogeniczności użyto siewki bakłażana (odmiana Black Beauty) w stadium trzeciego liścia. Test wykonano w trzech terminach, każdorazowo inokulując zawiesiną danego szczepu Cms 10 roślin bakłażana. W trakcie eksperymentu określano wzrokowo powierzchnię blaszek liściowych z charakterystycznymi objawami (do oceny użyto wszystkie w pełni rozwinięte liście), wyrażoną w procentach. Odnotowano również liczbę roślin z charakterystycznymi objawami (według 5-stopniowej skali: 1 - brak objawów; 2-3 - ciemnozielone, następnie jasnozielone zmiany na liściach, 4 - chlorozy, 5 - nekrozy) do całkowitej liczby siewek użytych do badań dla danego szczepu Cms (tab. 2). Jako kontrolę negatywną użyto siewki bakłażana, które inokulowano sterylnym 0,9\% roztworem $\mathrm{NaCl}$. Do określenia zależności między patogenicznością szczepów stwierdzoną na roślinach bakłażana a ilością produkowanego enzymu celulolitycznego, zastosowano współczynnik korelacji Pearsona.

W badaniu opisującym poziom mukoidalności szczepów użyto 7-dniową hodowlę bakterii (pożywka YPGA yeast peptone glucose agar - agar drożdżowo-peptonowoglukozowy, inkubacja w temperaturze $21^{\circ} \mathrm{C}$ ). $\mathrm{Na}$ wadze analitycznej odważano po $0,1 \mathrm{~g}$ inokulum bakteryjnego każdego szczepu, dodano $900 \mu \mathrm{l} 0,9 \% \mathrm{NaCl}$ (rozcieńczenie $10^{-1}$ ), a następnie wykonano $\mathrm{z}$ nich szereg 10 -krotnych rozcieńczeń $(0,9 \% \mathrm{NaCl})$ i posiew na podłoże YPGA (Dyrektywa Komisji 2006/56/WE). Wykonano pomiar gęstości optycznej (OD - optical density) otrzymanych zawiesin $\mathrm{w}$ rozcieńczeniu $10^{-3}$ na spektrofotometrze (Shimadzu UV-2100) przy długości fali $\lambda=600 \mathrm{~nm}$. Doświadczenie przeprowadzono $\mathrm{w}$ trzech powtórzeniach każdorazowo dokonując oceny wizualnej mukoidalności wyrosłych na podłożu YPGA kolonii Cms. Do analiz statystycznych użyto pakietu Statistica 7.1 PL, porównania szczegółowe wykonano testem post-hoc Tukeya (dla $\mathrm{p}<0,05)$. Dokonano korelacji Pearsona mukoidalności, wyrażoną pomiarem gęstości optycznej zawiesin z patogenicznością szczepów, określoną w teście biologicznym.

\section{Wyniki i dyskusja / Results and discussion}

Otrzymane wyniki przedstawiają duże zróżnicowanie szczepów Cms z kolekcji NCCPB pod względem patogeniczności stwierdzonej na roślinach bakłażana. Test biologiczny na roślinach bakłażana, zdaniem Bishopa i Slacka $(1987,1992)$ może charakteryzować patogeniczność szczepów Cms według przyjętej skali. Autorzy jako podstawę zróżnicowania szczepów podali tempo ich wzrostu in planta oraz produkcję czynników wirulencji indukujących więdnięcie w warunkach kontrolowanych. W badaniach własnych zastosowano 5-stopniową skalę objawów i więdnięcia. Dwa szczepy Cms: NCPPB 3898 i 3896 nie powodowały symptomów chorobowych na oberżynie. Objawy chorobowe na roślinach testowych dla pozostałych szczepów kształtowały się na poziomie od 6,1 do $38,4 \%$ powierzchni blaszek liściowych. Tylko jeden szczep Cms NCPPB 4053 powodował charakterystyczne więdnięcia i chlorozy liści na wszystkich badanych siewkach bakłażana (tab. 2).

Pomiary stref hydrolizy karboksymetylocelulozy w teście płytkowym wykazały również dużą niejednorodność w grupie badanych szczepów i oscylowały w przedziale od 0,33 do 4,29 $\mathrm{mm}$. Najniższe promienie strefy hydrolizy zaobserwowano u dwóch niemukoidalnych szczepów NCPPB 3898 i 3896, które nie powodowały symptomów chorobowych na roślinie testowej (tab. 2). Otrzymane wyniki pomiaru stref hydrolizy $\mathrm{cmc}$ odbiegają od wyników oceny rozkładu celulozy dla izolatów Cms pozyskanych z laboratoriów Państwowej Inspekcji Ochrony Roślin i Nasiennictwa (PIORiN) (Pastuszewska i Gryń 2013). W badaniach dotyczących aktywności celulolitycznej $C m s$ badacze wykorzystali również szczepy przechowywane długi czas w kolekcji Instytutu Hodowli i Aklimatyzacji Roślin - Państwowego Instytutu Badawczego. Autorzy zaobserwowali mniejszą aktywność enzymatyczną i mniejszą patogeniczność szczepów po długim przechowywaniu na sztucznych podłożach w porównaniu do izolatów otrzymanych z laboratoriów PIORiN. Nissinen i wsp. (2001) w eksperymencie z użyciem 4 szczepów otrzymali wartości pomiaru strefy rozkładu celulozy wynoszące maksymalnie 3,6 mm, przy nieco wyższych, w porównaniu do badań własnych, obserwowanych objawach na bakłażanie (56\%). Badaczom nie udało się jednak stwierdzić korelacji między aktywnością celulolityczną a wirulencją szczepów. W badaniach własnych wystąpiła korelacja między wielkością strefy hydrolizy celulozy a powierzchnią objawów chorobowych na bakłażanie wynosząca 0,7. Podobna zależność (korelacja 0,75) wystąpiła w badaniach Pastuszewskiej i Grynia (2013). Nissinen i wsp. (2001) podkreślają, że produkcja egzoenzymu rozkładającego celulozę jest niezbędna do wywoływania symptomów choroby, jednocześnie jednak sugerują, że obniżenie ekspresji genu celA powoduje trudności $\mathrm{w}$ diagnozie latentnej formy bakteriozy pierścieniowej. 
Tabela 2. Charakterystyka szczepów bakterii Clavibacter michiganensis subsp. sepedonicus

Table 2. Characteristic of bacterial strains of Clavibacter michiganensis subsp. sepedonicus

\begin{tabular}{|c|c|c|c|c|c|}
\hline $\begin{array}{l}\text { Szczep Cms } \\
\text { Strain of } C m s\end{array}$ & $\begin{array}{l}\text { Strefa hydrolizy } \\
\mathrm{cmc}^{1} \text {, średnia } \\
\text { Region of } \mathrm{cmc}^{1} \\
\text { hydrolysis, mean } \\
{[\mathrm{mm}]}\end{array}$ & $\begin{array}{c}\text { Ocena wizualna } \\
\text { mukoldalności } \\
\text { kolonii } C m s \\
\text { Visual } \\
\text { assessment } \\
\text { of } C m s \text { colony }\end{array}$ & $\begin{array}{c}\text { Gęstość optyczna } \\
\text { zawiesiny otrzymanej } \\
\text { z } 0,1 \mathrm{~g} \text { inokulum } \mathrm{Cms} \\
(1000 \times) \text {, średnia } \\
\text { The optical density } \\
\text { of the suspension } \\
\text { obtained from } 0.1 \mathrm{~g} \mathrm{Cms} \\
\text { inoculum }(1000 \times), \text { mean }\end{array}$ & $\begin{array}{c}\text { Liczba roślin } \\
\text { z objawami/całkowita } \\
\text { liczba inokulowanych } \\
\text { roślin } \\
\text { Number of plants } \\
\text { with symptoms/total } \\
\text { number of inoculated } \\
\text { plants }\end{array}$ & $\begin{array}{c}\text { Powierzchnia liści } \\
\text { bakłażana } \\
\text { z objawami, średnia } \\
\text { Eggplant leaf surface } \\
\text { with symptoms, mean } \\
\text { [\%] }\end{array}$ \\
\hline NCPPB 3898 & $0,33(0,47)^{2}$ & - & $0,59(0,01) \mathrm{a}$ & $0 / 30$ & 0 \\
\hline NCPPB 3896 & $0,58(0,32)$ & - & $0,58(0,05)$ a & $0 / 30$ & 0 \\
\hline NCPPB 378 & $2,83(0,24)$ & +++ & $0,09(0,03) \mathrm{d}$ & $12 / 30$ & 6,1 \\
\hline NCPPB 3385 & $1,75(0,50)$ & ++ & $0,38(0,09) b$ & $12 / 30$ & 7,8 \\
\hline NCPPB 3917 & $3,25(0,40)$ & +++ & $0,07(0,01) \mathrm{d}$ & $18 / 30$ & 13,9 \\
\hline NCPPB 379 & $3,04(0,21)$ & ++ & $0,27(0,09) \mathrm{bc}$ & $20 / 30$ & 15,8 \\
\hline NCPPB 2138 & $3,04(0,21)$ & + & $0,57(0,07) \mathrm{a}$ & $29 / 30$ & 17,1 \\
\hline NCPPB 2140 & $1,08(0,35)$ & - & $0,57(0,07) \mathrm{a}$ & $25 / 30$ & 19,8 \\
\hline NCPPB 4229 & $1,33(0,24)$ & ++ & $0,19(0,02) \mathrm{cd}$ & $26 / 30$ & 24 \\
\hline NCPPB 299 & $2,50(0,00)$ & + & $0,56(0,02) \mathrm{a}$ & $29 / 30$ & 26,2 \\
\hline NCPPB 3295 & $3,04(0,48)$ & +++ & $0,09(0,02) \mathrm{d}$ & $27 / 30$ & 28,4 \\
\hline NCPPB 3294 & $2,87(0,25)$ & +++ & $0,09(0,00) \mathrm{d}$ & $24 / 30$ & 29,6 \\
\hline NCPPB 3324 & $4,29(0,34)$ & +++ & $0,09(0,01) \mathrm{d}$ & $29 / 30$ & 29,6 \\
\hline NCPPB 3296 & $4,04(0,08)$ & +++ & $0,08(0,01) \mathrm{d}$ & $29 / 30$ & 34,5 \\
\hline NCPPB 4053 & $4,00(0,00)$ & +++ & $0,07(0,01) \mathrm{d}$ & $30 / 30$ & 38,4 \\
\hline
\end{tabular}

${ }^{1}$ sól sodowa karboksymetylocelulozy - carboxymethylcellulose sodium salt

2 odchylenie standardowe - standard deviation

- szczep niemukoidalny - non-mucoid strain

++ szczep średnio mukoidalny - medium mukoid strain

+++ szczep mukoidalny - mucoid strain

Średnie oznaczone tymi samymi literami nie różnią się istotnie przy $\mathrm{p}=0,05$

Averages followed by the same letters do not differ significantly at $\mathrm{p}=0.05$

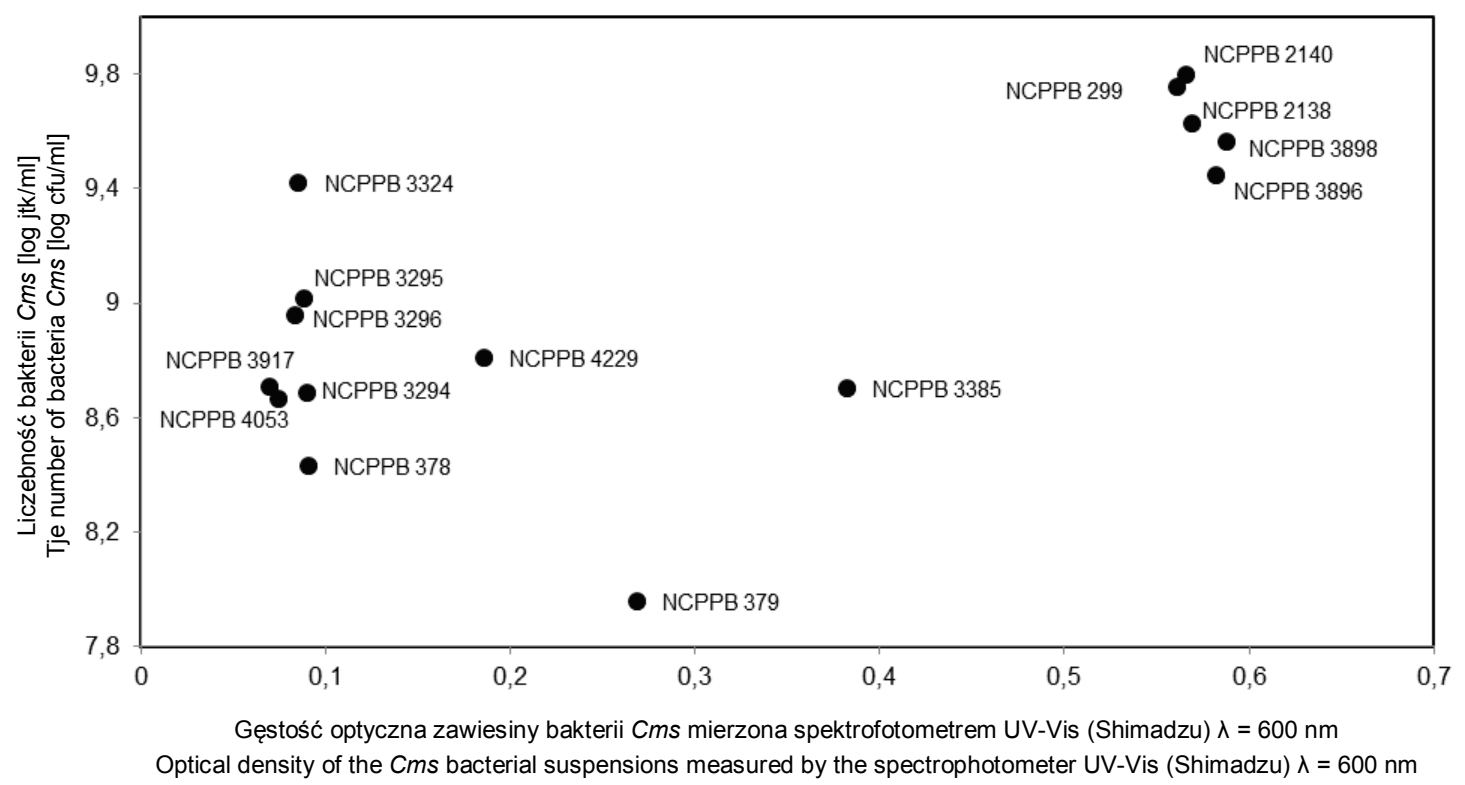

Rys. 1. Wykres rozrzutu pomiaru gęstości optycznej $\left(\mathrm{OD}_{600}\right)$ i liczebności bakterii Cms $(\log \mathrm{jtk} / \mathrm{ml})$ w zawiesinie wykonanej z $0,1 \mathrm{~g}$ inokulum (rozcieńczenie 1:1000)

Fig. 1. Dispersion plot optical density $\left(\mathrm{OD}_{600}\right)$ and number of $C m s$ bacteria $(\log \mathrm{cfu} / \mathrm{ml})$ in suspension made from $0.1 \mathrm{~g}$ inoculum (dilution 1:1000) 
W badaniach własnych podjęto próbę oceny zróżnicowania szczepów Cms pod względem ilości produkowanej otoczki egzopolisacharydowej (mukoidalności) i jej wpływu na patogeniczność bakterii stwierdzanej $\mathrm{w}$ teście biologicznym na bakłażanie. Liczebność bakterii w jednakowej naważce wynoszącej $0,1 \mathrm{~g}$ inokulum była różna w zależności od stopnia mukoidalności, co świadczyć może o ilości produkowanej otoczki mukoidalnej (rys. 1). Większa wartość średniej pomiaru gęstości optycznej zawiesiny odpowiada mniejszej ilości wytwarzanej otoczki śluzowej (EPS) w ocenie wizualnej kolonii. Westra i Slack (1992) dowiedli, że proporcje monosacharydów wchodzących w skład otoczki mukoidalnej badanych szczepów Cms były zróżnicowane. Autorzy wskazują możliwość fizycznej blokady wiązek przewodzących przez EPS, prowadzącą do więdnięcia rośliny. Badacze nie odnotowali jednak zależności użytych szczepów $C m s$, różniących się mukoidalnością, ze zdolnością wywoływania symptomów chorobowych na roślinie bakłażana i ziemniaka. W przypadku patogena blisko spokrewnionego z Cms - Clavibacter michiganensis subsp. michiganensis (Cmm), Bermpohl i wsp. (1996) zaobserwowali nieznacznie większe masy roślin pomidorów inokulowanych szczepami bakterii o zredukowanej produkcji EPS w porównaniu ze szczepami wirulentnymi. $\mathrm{W}$ doświadczeniu własnym na podstawie stopnia występowania objawów chorobowych na bakłażanie stwierdzono korelację wirulencji i wartości pomiaru gęstości optycznej, świadczącej o mukoidalności szczepów, wynoszącą $-0,54$. Lepsze zrozumienie roli otoczek muko- idalnych i egzoenzymów w patogeniczności szczepów Cms wymaga dodatkowych badań o szerszym zasięgu obejmującym kolonizację roślin żywicielskich, regulację ekspresji genów kodujących celulazy i szybkość namnażania patogena $\mathrm{w}$ roślinie. Opracowanie odpowiednich testów oceniających stopień wirulencji szczepów Cms jest pierwszym krokiem do wyjaśnienia mechanizmów odpowiedzialnych za występowanie objawów chorobowych na roślinie $\mathrm{i}$ skutecznej walki $\mathrm{z}$ bakteriozą pierścieniową ziemniaka w formie latentnej. Opracowywany test stwierdzający ilość wydzielanego egzopolisacharydu $\mathrm{z}$ próbki inokulum bakteryjnego na podstawie pomiaru spektrofotometrycznego i posiewu na podłoże stałe pozwoli, w przypadku skrajnie różniących się mukoidalnością szczepów $C m s$, na doprecyzowanie warunków prowadzonych testów patogeniczności.

\section{Wnioski / Conclusions}

1. Wykazano duże zróżnicowanie wirulencji szczepów Cms pochodzących z kolekcji NCPPB.

2. Stwierdzono istotny wpływ ilości produkowanego egzoenzymu celulazy na nasilenie symptomów chorobowych na roślinach bakłażana, a tym samym wirulencję szczepu.

3. Zaobserwowano znaczne zróżnicowanie szczepów Cms pod względem mukoidalności. Szczepy powodujące większe nasilenie objawów na bakłażanie były szczepami mukoidalnymi.

\section{Literatura / References}

Baer D., Gudmestad N.C. 1995. In vitro cellulolytic activity of the plant pathogen Clavibacter michiganensis ssp. sepedonicus. Canadian Journal of Microbiology 41 (10): 877-888.

Bentley S.D., Corton C., Brown S.E., Barron A., Clark L., Doggett J., Harris B., Ormond D., Quail M.A., May G., Francis D., Knudson D., Parkhill J., Ishimaru C.A. 2008. Genome of the actinomycete plant pathogen Clavibacter michiganensis subsp. sepedonicus suggests recent niche adaptation. Journal of Bacteriology 190 (6): 2150-2160.

Bermpohl A., Dreier J., Bahro R., Eichenlaub R. 1996. Exopolysaccharide in the pathogenic interaction of Clavibacter michiganensis subsp. michiganensis with tomato plants. Microbiological Research 151 (4): 1-9.

Bishop A.L., Slack S.A. 1987. Effect of inoculum dose and preparation, strain variation, and plant growth conditions on the eggplant assay for bacterial ring rot. American Potato Journal 64 (5): 227-234.

Bishop A.L., Slack S.A. 1992. Effect of infection with Clavibacter michiganensis subsp. sepedonicus Davis et al. on water relation in potato. Potato Research 35 (1): 59-63. DOI: 10.1007/BF02357724.

Danhorn T., Fuqua C. 2007. Biofilm formation by plant-associated bacteria. Annual Review of Microbiology 61 (1): 401-422.

Dyrektywa Komisji 2006/56/WE z dnia 12 czerwca 2006 r. zmieniająca załączniki do Dyrektywy Rady 93/85/EWG w sprawie zwalczania bakteriozy pierścieniowej ziemniaka. Dz. Urz. UE Nr L 182 z dnia 4 lipca 2006 r.

Gartemann K.H., Kirchner O., Engemann J., Gräfen I., Eichenlaub R., Burger A. 2003. Clavibacter michiganensis subsp. michiganensis: first steps in the understanding of virulence of a Gram-positive phytopathogenic bacterium. Journal of Biotechnology $106(2-3): 179-191$.

Harding M.W., Daniels G.D., Howard R.J. 2014. In vitro evaluations of microbial biofilms and their responses to chemical disinfectants. Acta Horticulturae 1053: Proceedings of the Second International Symposium on Discovery and Development of Innovative Strategies for Postharvest Disease Management: 245-255. DOI: 10.17660/ActaHortic.2014.1053.27.

Hill B., Kalischuk M., Waterer D.R., Bizimungu B., Howard R. 2011. An environmental model predicting bacterial ring rot symptom expression. American Journal of Potato Research 88 (3): 294-301.

Hogenhout S.A., Loria R. 2008. Virulence mechanisms of Gram-positive plant pathogenic bacteria. Current Opinion in Plant Biology 11 (4): 449-456.

Holtsmark I., Takle G.W., Brurberg M.B. 2008. Expression putative virulence factors in the potato pathogen Clavibacter michiganensis subsp. sepedonicus during infection. Archives of Microbiology 189 (2): 131-139.

Jahr H., Bahro R., Ahlemeyer J., Eichenlaub R. 1999. Interactoins between Clavibacter michiganensis and its host plants. Environmental Microbiology 1 (2): 113-118. 
Kawchuk L.M., Lynch D.R., Kozub G.A., Nelson G.A., Kulcsar F., Fujimoto D.K. 1998. Multi-year evaluation of Clavibacter michiganensis subsp. sepedonicus disease symptoms in cultivated potato genotypes. American Journal of Potato Research 75 (6): $235-243$.

Laine M.J., Haapalainen M., Wahlroos T., Kankare K., Nissinen R., Kassuwi S., Metzler M.C. 2000. The cellulose encoded by the native plasmid of Clavibacter michiganensis ssp. sepedonicus plays a role in virulence and contains an expansin-like domain. Physiological and Molecular Plant Pathology 57 (5): 221-233.

Meletzus D., Bermphol A., Dreier J., Eichenlaub R. 1993. Evidence for plasmid-encoded virulence factors in the phytopathogenic bacterium Clavibacter michiganensis ssp. sepedonicus NCPPB 382. Journal of Bacteriology 175 (7): 2131-2136.

Metzler M.C., Laine M.J., De Boer S.H. 1997. The status of molecular biological research on the plant pathogenic genus Clavibacter. FEMS Microbiology Letters 150: 1-8.

Nissinen R., Kassuwi S., Peltola R., Metzler M.C. 2001. In planta - complementation of Clavibacter michiganensis subsp. sepedonicus strains deficient in cellulose production or HR induction restores virulence. European Journal of Plant Pathology 107 (2): $175-182$.

Pastrik K.H. 2000. Detection of Clavibacter michiganensis ssp. sepedonicus in potato tubers by multiplex PCR with coamplification of host DNA. European Journal of Plant Pathology 106 (2): 155-165.

Pastuszewska T., Gryń G. 2013. Aktywność celulolityczna a wirulencja Clavibacter michiganensis subsp. sepedonicus. Biuletyn Instytutu Hodowli i Aklimatyzacji Roślin 270: 123-131.

Pastuszewska T., Junosza Kisielewska I. 2004. Reakcja wybranych odmian ziemniaka na inokulację bakteriami Clavibacter michiganensis subsp. sepedonicus. [Response of potato cultivars to inoculation with bacteria Clavibacter michiganensis subsp. sepedonicus]. Progress in Plant Protection/Postępy w Ochronie Roślin 44 (2): 1014-1016.

Ramey B.E., Koutsoudis M., von Bodman S.B., Fuqua C. 2004. Biofilm formation in plant-microbe associations. Current Opinion in Microbiology 7 (6): 602-609.

Rudrappa T., Biedrzycki M.L., Bais H.P. 2008. Causes and consequences of plant-associated biofilms. FEMS Microbiology Ecology 64: $153-166$.

van der Wolf J.M., Elphinstone J.G., Stead D.E., Metzler M., Müller P., Karjalainen R. 2005a. Epidemiology of Clavibacter michiganensis subsp. sepedonicus in relation to control of bacterial ring rot. Plant Research International B.V. Wageningen, February 2005, 38 pp.

van der Wolf J.M., van Beckhoven J., Hukkanen A., Karjalainen R., Muller P. 2005b. Fate of Clavibacter michiganensis ssp. sepedonicus, the causal organism of bacterial ring rot of potato, in weeds and field crops. Journal of Phytopathology 153 (6): 358-365.

Westra A.A.G., Arneson C.P., Slack S.A. 1994. Effect of interaction of inoculum dose, cultivar, and geographic location on the development of foliage symptoms of bacterial ring rot of potato. Phytopathology 84 (4): 410-415.

Westra A.A.G., Slack S.A. 1992. Isolation and characterization of extracellular polysaccharide of Clavibacter michiganensis subsp. sepedonicus. Phytopathology 82 (10): 1193-1200. 